\title{
STRATEGIC LEADERSHIP AND SUSTAINABILITY PERFORMANCE OF SMALL AND MEDIUM ENTERPRISES
}

\author{
Solomon Akpoviroro Kowo ${ }^{1, a, *}$ and Olufemi Amos Akinbola ${ }^{2}$ \\ ${ }^{1}$ Department of Business and Entrepreneurship, Kwara State University, Malete Nigeria \\ ${ }^{2}$ Department of Business Administration, Federal University of Agriculture, Abeokuta \\ akowosolomon@gmail.com \\ *Corresponding author
}

Cite as: Kowo, S.A., Akinbola, O.A. (2019). Strategic leadership and sustainability performance of small and medium enterprises. Ekonomicko-manazerske spektrum, 13(1), 38-50.

Available at: dx.doi.org/10.26552/ems.2019.1.38-50

\begin{abstract}
The small-scale industry in Nigeria is considered to be an important element to the growth of the economy in contributing to the gross domestic products of the economy, and it has been of contention that strategic leadership has influenced and sustained the performance of small and medium enterprises. As such, the main objective of the study is to examine how the exercising of strategic leadership has influenced and sustained the performance of small and medium enterprises in Nigeria in terms of social impact. About 300 questionnaires were administered to small sized companies. The study found that there is a significant influence of strategic planning on sustaining small and medium enterprises profit performance and the results indicated that the managers that sustain profitability performance are those that are strategic in planning. The study discovers that the return on investment of small and medium enterprise depends on the appropriateness of its leadership practices. The study recommends that small-sized companies should be effective in their strategy implementation in order to achieve the corporate objectives of indigenous small and medium enterprises.
\end{abstract}

Keywords: entrepreneur, leadership, organizational performance, social responsibility

JEL Classification: M2, G3

\section{Introduction}

Despite the fact that Africa is in tremendous need of effective leadership, there are a few consistent studies of leadership. (Davis, 2007; Avolio, 2007; Avolio et al., 2003) Following the adoption of Economic Reform Programme in Nigeria in 1981, there have been several decisions to switch from capital intensive and large scale industrial projects, which were based on the philosophy of import development to small and medium scale enterprises, which have better prospects for economic growth, thereby generating the required goods and services that will propel the economy of Nigeria towards development. (Rowe, 2001; Careless, 2004) In order to succeed and survive these turbulent business environments, organizations need to adapt to these environmental changes by means of strategic leadership. (Goodavzi, 2006; Almold et al., 2008) Ashibogwu (2008) noted that one of the reasons for the death of these organizations is their failure to make use of market research to ascertain demand and assess the suitability of the proposed offering as well as maintaining a high level of customer patronage. Inappropriate leadership styles and lack of succession plans are parts of the reasons for the untimely death of small and medium enterprises. (Bochnke and Bontis, 2003) However, there is sufficient 
literature on the different types of "leadership" there is not enough on strategic leadership, which concerns small and medium scale Enterprises in Nigeria. Given the significant role of Small and Medium Enterprises in Nigeria's economic development as well as other countries in Africa, there is need to fill the above research gap caused by failure to adopt strategic leadership option. (Burke, 2006; Bloom, 2000) While there is sufficiency of information related to the phenomenon of leadership, the concept of effective "strategic leadership" is vague, and still requires much investigation. (Anthony, 2005) Organization culture more than other variables show an organization is an ability to survive. "Leadership is the process of motivating and directing others towards the accomplishment of objectives. (Chiek, 2001) It involves an attempt at influencing the behaviour of others for goals. In support of the above definition. Here zeal reflects earnestness and intensity in the execution of the work while confidence reflects earnestness and intensity in the execution of the work while confidence reflects the experience and technical ability. While a person can be a leader, he may not be a manager. (Esposito and Sanchis-Llopis, 2018) At this point in time, it is essential to explain that the term leadership and manager are not synonymous. (Moron, 2004) "The term leader and manager are not necessarily interchangeable because leadership is a subclass of management. (Clement and Themba, 2013)

Without good leadership, an organization cannot achieve optimum efficiency. The challenge of the study is to examine the influence of strategic leadership in enhancing the strategies of organizational leaders and their effectiveness in helping to achieve a sustainable performance of small and medium enterprises in Nigeria. (Day, 2000; Day et al., 2004) In today's competitive environment, running a small business by means of strategic leadership is not just a good idea; it is a requirement for success and sustainability. (Fry, 2003) The study seeks to answer the following questions (i) In which form does strategic planning assist in sustaining performance of small and medium enterprises (ii) Does return on investment of indigenous Small and Medium Enterprises affect the performance of indigenous small and medium enterprises. (Fenwick and Gayle, 2008)

\section{Literature Review}

Leadership is the process of motivating and directing others towards the accomplishment of objectives. It involves an attempt at influencing the behaviour of others for goals. In support of the above definition. At this point in time, it is essential to explain that the term leadership and manager are not synonymous. (Goldstein and Ford, 2002) "The term leader and manager are not necessarily interchangeable because leadership is a subclass of management. Managers perform the function of creating, planning, organizing, motivating, communicating and controlling. Included within these functions is the necessity to lead effectively, which may affect his ability to manage, but a leader needs only to influence the behaviour of others. He is not necessarily required to perform all the function of a manager." (Liao and Joshi, 2004) In fact, he is not even required to lead his followers in the right decision. Hou and Li (2019) postulates that the action of committing employees to contribute their best to organizations depends on a good strategic plan of the management. Since human beings become members of an organization in order to achieve certain objectives, the extent to which they are active members depends on how much they are convinced that their membership will enable them to achieve their predominated objectives. (Bowery, 2004; Aime et al., 2010)

The concept of leadership is well-established in management literature. Strategic leadership is getting people to do things in a well-structured and knowledgeable way. (Ogundele, 2006; Bengelsdjik et al., 2006) It entails changing an organization and making active choices among plausible alternatives and depends on the development of others and mobilizing them to get the 
job done in a systematic and strategic way through a well-formulated organization plans and objectives. (Ogundele, 2006) In the recent times, leadership has increasingly been associated not with command and control but with the concept of inspiration of getting along with other people and creating a vision, which others can identify. (Taffinder, 2006; Ahearne et al., 2005)

A leaders performance depends as much as on the organization, on the leaders' own attributes. Except perhaps for the usual case, it is simply not meaningful to speak of an effective leader; we can only speak of a leader who tends to be effective in one situation and ineffective in another. (Davis, 2007) Pitelis and Wagner (2019) provide critical competitive advantages to public and private sector organizations. During this same period, heightened issues about the social accountability of the organization also occupied management positions. (Brown, 2011; Armstrong, 2009; Hartline and Wooldridge, 2003) The traditional logic of organizing is to give simple work to employees at the bottom of the pyramid who then report through a supervisor up a hierarchical chain of command to senior executives who provide direction, coordinate and control. This does not work well for organizations managing knowledge-intensive tasks. (Hoyt and Mulph, 2003; Ijeoma, 2010)

Ohio State studies identify two dimensions of strategic leadership behaviour by subordinates A leader is characterized as high in initiating structure could be described in terms such as assigning group members to a particular task. A leader who is high in consideration could be described as one who helps subordinates as equals. In conclusion. The Ohio state studies suggested that the high-high style generally resulted in positive outcomes. (Rowe, 2001)

\section{Figure 1: Porter's five forces model \\ Risk of entry by}

Potential competitors
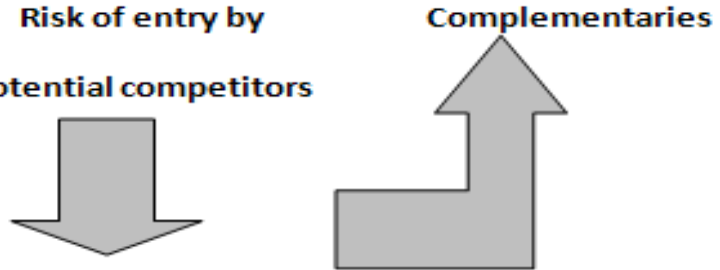

Bargaining power

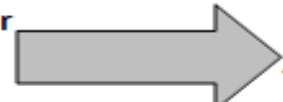

INTENSITY OF RIVALRY Of suppliers
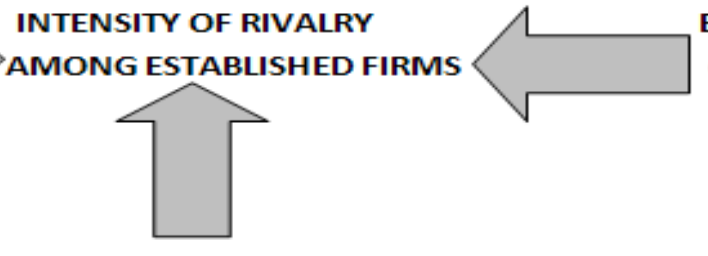

Bargaining Power of buyers

Threat of Substitutes

Source: Harvard Business Review

Rowe (2001) claims, that there are basically dual forms of participation namely direct and indirect participation. Direct participation in decision -making is the participative processes whereby employees are involved in a decision relating to their immediate task or environment. (Levewis et al., 2002; Atkin et al., 2017) This form of participation is mainly found in productivity bargaining which is an arrangement between a worker and his employer to the effect that an increase in his productivity will make him earn an additional wage. Productivity bargaining arises mainly in circumstances where working practices need changes. (Ehrhart, 2004; Sine, 2016)

An indirect form of participation is the participation process whereby employees are involved in decision making through their selected representatives or delegates. Looking at the strategy applied by managers to involve employees in decision making in an organization, participative principles is normally employed to achieve the desired result. (Alajmi, 2006) 
Managers have many opportunities for involving subordinates in organizational planning and decision- making. He identified four participative methods, which managers most likely apply. (Maliranta and Nurmi, 2019)

i. Delegation: it means the transfer of authority from the superiors to the subordinates

ii. Committee Action: Committees are a vital mean of continually gaining inputs from a large number of organizational members. Most companies have certain standing committees to deal with continuing or receiving problems facing the organization. These could be related to corporate policy goals and operations. Depending upon the organizational structure special committees may be established to deal with budgets, employment policies, grievances, disciplinary problems and a variety of other organizational problems and activities. (Huang et al., 2010)

iii. Question Asking: Managers who respect the knowledge, opinions and judgment of their subordinates may achieve a relatively high level of participation by simply asking questions. Here, the participative leader asks for information and insights that will improve the quality of the responsibility of their subordinates in terms of intelligence and problem-solving. (Birou et al., 2019)

iv. Shared Goals: Participative leaders are prone to become involved in management by objectives and similar goals - oriented programs. Ideally, an MBO programme is highly participative. (Jung and Arlio, 2000; Javad et al., 2013)

Strategic Leadership can be written as; $\mathrm{P}=\mathrm{f}(\mathrm{SL})$, where Performance $(\mathrm{P})$ is the dependent variable with these components; profitability, return on investment, workers' motivation and corporate image, while Strategic Leadership (SL) is the independent variable with these components; as strategic planning, leadership practices, social responsibility, management control and strategy implementation. (Joshi et al., 2011; Hallen, 2017)

$\mathrm{P}$ is a variable with several components breaking

$$
\text { Por } Y=y_{1}, y_{2}, y_{3}, \ldots, y_{n}
$$

where

$y_{1} \quad$ profitability

$y_{2} \quad$ return on investment

$y_{3} \quad$ workers' motivation

$y_{4} \quad$ organizational objective

$$
\text { SLor } X=x_{1}, x_{2}, x_{3}, \ldots, x_{n}
$$

where

$x_{1} \quad$ strategic planning

$x_{2} \quad$ leadership practices

$x_{3} \quad$ social responsibility

$x_{4} \quad$ strategy implementation

\section{Methodology}

To access our research variables a cross-sectional survey design was adopted on nongovernmental Agricultural Entrepreneurship operating in Port-Novo, Benin Republic. The first 
group, which comprises the CEO/Director, managers and supervisors, while the second group comprises the junior staff members and casual workers of the researched organization. Therefore, categories of participants were sourced from the employees and casual workers of Songhai Centre in Port-Novo, Benin Republic. A single organization namely Songhai Centre was researched on the platform of its strategic leadership influence on sustaining performance. Therefore, a total number of 133 participants was sourced. The population statistical formula postulated by Guilford and Fruchter (1973) was used for this study $\sum\left[1+N\left(e^{2}\right)\right]$; where: $n=$ The desired sample size to be determined, $N=$ Total population and $e=$ Accepted error limit 0.05 on the basis of $95 \%$ confidence level The desired sample size $n=300$ respondents. Simple random sampling method was chosen and used in the choice of the organization population sample of 133. (Malagueno, 2018) Simple random sampling because of the homogenous characteristics of the population of the study, that is, CEO/Director, managers, supervisors, junior staff and casual workers in the researched organization, and the ease of use of the table of random numbers. Also, each element has an equal chance of being selected and representational. Two types of the research instrument, questionnaire and in-depth interviewing were chosen because of the nature of this study. A well-structured questionnaire was drawn and used to gather information from the CEO/Director, managers, supervisors, junior staff and casual workers of the researched organization. The questionnaire was divided into four (4) sections, A-D: The first two sections, A-B, contained questions on the objectives of the research study, while the third section, $\mathrm{C}$, contained questions on the background information about the organizations and the respondents respectively. Views relating to age, sex, educational qualifications and years of experience of the particular respondents were required; while the date of establishment, incorporation, status, number of employees is demanded for 5-points summated rating scale popularly called Likert scale was used with calibration of Strongly Agree (SA), Agree (A), Undecided (U), Disagree (D), and Strongly Disagree (SD). Values of 5, 4, 3, 2 and 1 respectively were assigned in descending order to each calibration in measuring the responses; Likert scale was used so as enable the researcher to compare easily responses among individual respondents on one hand, and responses between groups on the other hand. One hundred and thirty-three (133) copies of the questionnaire were administered among the workforce of the organization studied. The researcher makes use of reliability test and was conducted by means of Cronbach Alpha Test. Statistical Packages for Social Science (SPSS) was employed. Analysis of Variance (ANOVA) adopted for testing the two stated hypotheses.

\section{Results}

Table 1: Distribution of respondents and response rate

\begin{tabular}{ccc}
\hline Respondents Occupation & Questionnaire administered (sampled) & Percentage of total response (\%) \\
\hline Top Level & 92 & 35.0 \\
Middle Level & 33 & 12.5 \\
Lower Level & 138 & 52.5 \\
Total & 263 & 100.0 \\
Gender/Category & Questionnaire administered (sampled) & Percentage of total response (\%) \\
Male & 149 & 56.7 \\
Female & 114 & 43.3 \\
No of Returned & 263 & 87 \\
No of Not Returned & 37 & 13 \\
Total no of Questionnaires & 240 & 100 \\
\hline
\end{tabular}

Source: Field Survey 2018 
The data analysed in the frequency table drawn for easy interpretation. Correlation and regression were used to test the hypothesis. In other words, this chapter presents a platform for the presentation and analysis of data collected by the researcher during the research and is presented in a suitable and easy form for understanding so as to achieve the objective of the study stated in chapter one. The population considered in this study was 1200 . A sample size of 300 was used, with $87 \%$ return rate. It shows that the questionnaires were filled by 114 females (56.7\%) and 149 males (43.3\%) and therefore, there were more male respondents than the female respondents in this survey. Classifies the respondents by marital status, the table shows that 140 of the respondents are single (53.2\%). Following tables show the descriptive statistics of strategic leadership and organizational performance.

Table 2: Strategic plans are considered an integral part of the organization

\begin{tabular}{cccccc}
\hline & & Frequency & Percent & Valid Percent & $\begin{array}{c}\text { Cumulative } \\
\text { Percent }\end{array}$ \\
\hline \multirow{3}{*}{ Valid } & strongly disagree & 30 & 11.4 & 11.4 & 11.4 \\
& disagree & 25 & 9.5 & 9.5 & 20.9 \\
& undecided & 27 & 10.3 & 10.3 & 31.2 \\
& agree & 45 & 17.1 & 17.1 & 48.3 \\
& strongly agree & 136 & 51.7 & 51.7 & 100.0 \\
\hline
\end{tabular}

Source: Field Survey 2018

The opinions of respondents on strategic plans are considered to be an integral part of the organization. It shows that $30(11.4 \%)$ of respondents strongly disagree, $25(9.5 \%)$ disagree,27(10.3\%) are undecided, 45(17.1\%) agree, and 136(51.7\%) strongly agree that strategic plans are considered to be an integral part of the organization

Table 3: Strategic plans are put in place to sustain the company

\begin{tabular}{cccccc}
\hline & Frequency & Percent & Valid Percent & $\begin{array}{c}\text { Cumulative } \\
\text { Percent }\end{array}$ \\
\hline \multirow{4}{*}{ Valid } & strongly disagree & 52 & 19.8 & 19.8 & 19.8 \\
& disagree & 15 & 5.7 & 5.7 & 25.5 \\
& undecided & 129 & 49.0 & 49.0 & 74.5 \\
& agree & 30 & 11.4 & 11.4 & 85.9 \\
& strongly agree & 37 & 14.1 & 100.0 & 100.0 \\
\hline
\end{tabular}

Source: Field Survey 2018

The opinion of respondents on strategic plans are put in place to sustain the company. It shows that 52(19.8\%) of respondents strongly disagree,15(5.7\%) disagree,129(49.0\%) are undecided,30(11.4\%) agree, and 37(14.1\%) strongly agree that strategic plans are put in place to sustain the company.

Table 4: Strategic plan is used as a tool for achieving corporate objective

\begin{tabular}{|c|c|c|c|c|c|}
\hline & & Frequency & Percent & Valid Percent & $\begin{array}{c}\text { Cumulative } \\
\text { Percent }\end{array}$ \\
\hline \multirow[t]{3}{*}{ Valid } & strongly disagree & 26 & 9.9 & 9.9 & 9.9 \\
\hline & disagree & 31 & 11.8 & 11.8 & 21.7 \\
\hline & undecided & 26 & 9.9 & 9.9 & 31.6 \\
\hline
\end{tabular}




\begin{tabular}{ccccc} 
agree & 95 & 36.1 & 36.1 & 67.7 \\
strongly agree & 85 & 32.3 & 32.3 & 100.0 \\
total & 263 & 100.0 & 100.0 & \\
\hline
\end{tabular}

Source: Field Survey 2018

The opinion of respondents on the strategic plan is used as a tool for achieving corporate objective, it shows that 26(9.9\%) of respondents strongly disagree, 31(11.8\%) disagree, 26 $(9.9 \%)$ are undecided, $95(36.1 \%)$ agree, and 85(32.3\%) strongly agree.

Table 5: The company revenue has been impressive in recent years

\begin{tabular}{cccccc}
\hline & Frequency & Percent & Valid Percent & $\begin{array}{c}\text { Cumulative } \\
\text { Percent }\end{array}$ \\
\hline Valid & strongly disagree & 9 & 3.4 & 3.4 & 3.4 \\
& disagree & 29 & 11.0 & 11.0 & 14.4 \\
& undecided & 26 & 9.9 & 9.9 & 24.3 \\
& agree & 154 & 58.6 & 58.6 & 82.9 \\
& strongly agree & 45 & 17.1 & 17.1 & 100.0 \\
& total & 263 & 100.0 & 100.0 & \\
\hline
\end{tabular}

Source: Field Survey 2018

The opinion of respondents on whether the company's revenue has been impressive in recent years, it shows that $9(3.4 \%)$ of respondents strongly disagree, $29(11.0 \%)$ disagree, $26(9.9 \%)$ are undecided,154(58.6\%) agree, and 45(17.1\%) strongly agree.

Table 6: Overall profit objective has been realistic

\begin{tabular}{cccccc}
\hline & Frequency & Percent & Valid Percent & $\begin{array}{c}\text { Cumulative } \\
\text { Percent }\end{array}$ \\
\hline Valid & strongly disagree & 26 & 9.9 & 9.9 & 9.9 \\
& disagree & 31 & 11.8 & 11.8 & 21.7 \\
& undecided & 26 & 9.9 & 9.9 & 31.6 \\
& agree & 95 & 36.1 & 36.1 & 67.7 \\
& strongly agree & 85 & 32.3 & 100.0 & 100.0 \\
\hline
\end{tabular}

Source: Field Survey 2018

The opinion of respondents on whether overall profit objective has been realistic, it shows that $26(9.9 \%)$ of respondents strongly disagree, 31(11.8\%) disagree, 26 (9.9\%) are undecided,95(36.1\%) agree, and 85(32.3\%) strongly agree.

Table 7: Return on investment has been impressive

\begin{tabular}{cccccc}
\hline & Frequency & Percent & Valid Percent & $\begin{array}{c}\text { Cumulative } \\
\text { Percent }\end{array}$ \\
\hline Valid & strongly disagree & 22 & 8.4 & 8.4 & 8.4 \\
& disagree & 52 & 19.8 & 19.8 & 28.1 \\
& undecided & 24 & 9.1 & 9.1 & 37.3 \\
& agree & 115 & 43.7 & 43.7 & 81.0 \\
& strongly agree & 50 & 19.0 & 19.0 & 100.0 \\
& total & 263 & 100.0 & 100.0 & \\
\hline
\end{tabular}

Source: Field Survey 2018 
Table 7 classifies the opinion of respondents on whether the return on investment has been impressive, it shows that $22(8.4 \%)$ of respondents strongly disagree, 52 (19.8\%) disagree, 24 $(9.1 \%)$ are undecided,115(43.7\%) agree, and 50(19.0\%) strongly agree.

Table 8: There is a call from the public for investment in the firm

\begin{tabular}{cccccc}
\hline & Frequency & Percent & Valid Percent & $\begin{array}{c}\text { Cumulative } \\
\text { Percent }\end{array}$ \\
\hline Valid & strongly disagree & 15 & 5.7 & 5.7 & 5.7 \\
& disagree & 28 & 10.6 & 10.6 & 16.3 \\
& undecided & 35 & 13.3 & 49.0 & 29.7 \\
& agree & 129 & 49.0 & 21.3 & 78.7 \\
& strongly agree & 56 & 100.0 & 100.0 & 100.0 \\
\hline
\end{tabular}

Source: Field Survey 2018

The opinion of respondents on whether there is a call from the public for investment in the firm, it shows that $15(5.7 \%)$ of respondents strongly disagree, 28 (10.6\%) disagree, $35(13.3 \%)$ are undecided,129(49.0\%) agree, and 56(21.3\%) strongly agree.

Table 9: Investment in years before in the firm has yielded above expectation

\begin{tabular}{cccccc}
\hline & Frequency & Percent & Valid Percent & $\begin{array}{c}\text { Cumulative } \\
\text { Percent }\end{array}$ \\
\hline Valid & strongly disagree & 16 & 6.1 & 6.1 & 6.1 \\
& disagree & 12 & 4.6 & 4.6 & 10.6 \\
& undecided & 34 & 12.9 & 12.9 & 23.6 \\
& agree & 129 & 49.0 & 49.0 & 72.6 \\
& strongly agree & 72 & 27.4 & 27.4 & 100.0 \\
\hline
\end{tabular}

Source: Field Survey 2018

The opinion of respondents on whether the investment in years before in the firm has yielded above expectation, it shows that $16(6.1 \%)$ of respondents strongly disagree $12(4.6 \%)$ disagree, $34(12.9 \%)$ are undecided,129(49.0\%) agree, and 72(27.4\%) strongly agree.

Table 10: Leadership practices have effects on return on investment

\begin{tabular}{|c|c|c|c|c|c|}
\hline & & Frequency & Percent & Valid Percent & $\begin{array}{c}\text { Cumulative } \\
\text { Percent }\end{array}$ \\
\hline \multirow[t]{6}{*}{ Valid } & strongly disagree & 15 & 5.7 & 5.7 & 5.7 \\
\hline & disagree & 31 & 11.8 & 11.8 & 17.5 \\
\hline & undecided & 17 & 6.5 & 6.5 & 24.0 \\
\hline & agree & 93 & 35.4 & 35.4 & 59.3 \\
\hline & strongly agree & 107 & 40.7 & 40.7 & 100.0 \\
\hline & total & 263 & 100.0 & 100.0 & \\
\hline
\end{tabular}

Source: Field Survey 2018

The opinion of respondents on whether leadership practices have effects on return on investment, it shows that $15(5.7 \%)$ of respondents strongly disagree $31(11.8 \%)$ disagree, $17(6.5 \%)$ are undecided 93(35.4\%) agree, and 107(40.7\%) strongly agree. 


\section{Test of Hypothesis 1}

$\mathrm{H}_{0}$ : There is no significant influence of strategic planning on sustaining Small and Medium Enterprise profit performance.

$\mathrm{H}_{1}$ : There is significant influence of strategic planning on sustaining Small and Medium Enterprise profit performance.

Table 11: Model Summary

\begin{tabular}{ccccc}
\hline Model & R & R Square & $\begin{array}{c}\text { Adjusted R } \\
\text { Square }\end{array}$ & $\begin{array}{c}\text { Std. Error of the } \\
\text { Estimate }\end{array}$ \\
\hline 1 & $.152(\mathrm{a})$ & .023 & .019 & .715 \\
\hline
\end{tabular}

a Predictors: (Constant), STRATEGIC PLAN

Source: output of SPSS

This table above is the model summary. It shows how much of the variance in the dependent variable (sustaining Small and Medium Enterprise profit performance.) is explained by the model (strategic planning). In this case, the $\mathrm{R}$ square value is .023. Expressed by a percentage, this means that our model explains $2.3 \%$ of the variance in the dependent variable of sustaining Small and Medium Enterprise profit performance. The adjusted R square shows .023, while the error of estimate indicates 0.715 , which signifies the error term that was not captured in the model.

Table 12: ANOVA(b) test

\begin{tabular}{ccccccc}
\hline \multirow{2}{*}{ Model } & & $\begin{array}{c}\text { Sum of } \\
\text { Squares }\end{array}$ & Df & Mean Square & F & Sig. \\
\hline \multirow{2}{*}{1} & Regression & 3.134 & 1 & 3.134 & 6.136 & $.014(\mathrm{a})$ \\
& Residual & 133.301 & 261 & .511 & & \\
\hline
\end{tabular}

a Predictors: (Constant), STRATEGIC PLAN

$b$ Dependent Variable: PROFITABILITY

Source: output of SPSS

The ANOVA table tests the null hypothesis to determine if it is statistically significant. From the results, the model in this table is statistically significant (Sig =.014) and hence the null hypothesis should be rejected.

Table 13: Coefficients(a)

\begin{tabular}{|c|c|c|c|c|c|c|}
\hline & \multirow{2}{*}{ Model } & \multicolumn{2}{|c|}{$\begin{array}{l}\text { Unstandardized } \\
\text { Coefficients }\end{array}$} & \multirow{2}{*}{$\begin{array}{c}\text { Standardized } \\
\text { Coefficients } \\
\text { Beta }\end{array}$} & \multirow{2}{*}{$\begin{array}{l}\mathbf{t} \\
\mathbf{B}\end{array}$} & \multirow{2}{*}{$\begin{array}{c}\text { Sig. } \\
\text { Std. Error }\end{array}$} \\
\hline & & B & Std. Error & & & \\
\hline \multirow{2}{*}{1} & (Constant) & 3.280 & .231 & & 14.195 & .000 \\
\hline & STRAGEGICPLAN & .171 & .069 & .152 & 2.477 & .014 \\
\hline
\end{tabular}

a Dependent Variable: PROFITABILITY

Source: output of SPSS

In this table, the beta coefficient of the independent variable is .171. This means that change in sustaining Small and Medium Enterprise profit performance could be explained by the dependent variable, which is strategic planning. 


\section{Test of Hypothesis 2}

$\mathrm{H}_{0}$ : The return on investment of Small and Medium Enterprise does not depend on the appropriateness of its leadership practices.

$\mathrm{H}_{1}$ : The return on investment of Small and Medium Enterprises depend on the appropriateness of its leadership practices.

Table 14: Model Summary

\begin{tabular}{ccccc}
\hline Model & R & R Square & Adjusted R Square & Std. Error of the Estimate \\
\hline 1 & .887 (a) & .787 & .786 & .358 \\
\hline
\end{tabular}

a Predictors: (Constant), Management gives room for employees suggestions, The leadership style encourages good ideas

Source: output of SPSS

The result indicates how much of the variance in the dependent variable (return on investment) is explained by the model (appropriateness of its leadership practices). $\mathrm{R}$ square value is 0.787 , which shows that our model explains $78.7 \%$ of the variance in the dependent variable of return on investment. The adjusted $\mathrm{R}$ square shows 0.787 , while the error of estimate indicates 0.358 , which signifies the error term that was not captured in the model.

Table 14: ANOVA(b) test

\begin{tabular}{ccccccc}
\hline \multicolumn{1}{l}{ Model } & $\begin{array}{c}\text { Sum of } \\
\text { Squares }\end{array}$ & Df & Mean Square & F & Sig. \\
\hline \multirow{2}{*}{1} & Regression & 123.095 & 2 & 61.548 & 481.344 & $.000(\mathrm{a})$ \\
& Residual & 33.245 & 260 & .128 & & \\
& Total & 156.341 & 262 & & & \\
\hline
\end{tabular}

a Predictors: (Constant), Management gives room for employees suggestions, The leadership style encourages good ideas

$b$ Dependent Variable: ROI

Source: output of SPSS

This table shows the assessment of the statistical significance of the result. The ANOVA table tests the null hypothesis to determine if it is statistically significant. From the results, the model in this table is statistically significant $(\mathrm{Sig}=.0001)$ and hence the null hypothesis should be rejected.

Table 15: Coefficients(a)

\begin{tabular}{ccccccc}
\hline Model & \multicolumn{2}{c}{$\begin{array}{c}\text { Unstandardized } \\
\text { Coefficients }\end{array}$} & $\begin{array}{c}\text { Standardized } \\
\text { Coefficients }\end{array}$ & t & Sig. \\
B & Std. Error & Beta & B & Error \\
\hline 1 & 1.020 & .090 & & 11.288 & .000 \\
$\begin{array}{c}\text { The leadership style } \\
\text { encourages good ideas }\end{array}$ & .308 & .018 & .494 & 16.827 & .000 \\
$\begin{array}{c}\text { Management gives room for } \\
\text { employees suggestions }\end{array}$ & .447 & .021 & .634 & 21.588 & .000 \\
\hline
\end{tabular}

a Dependent Variable: ROI

Source: output of SPSS 
In this table, the beta coefficient of the independent variables are 0.308 and 0.447 . This means that change in return on investment could strongly be explained by the dependent variable, which is the appropriateness of its leadership practices.

\section{Discussion}

(i) The study found that there is a significant influence of strategic planning on sustaining Small and Medium Enterprise profit performance, this can be linked with how managers manage plans in both short and long-term basis to avoid, unnecessary wastages, employee turnover, business losses and revenue generations. The findings in this study showed that if managers can manage plans as they should, profitability would be sustained, in accordance with Ssebunya (2019).

(ii) The findings reveal that the return on investment of Small and Medium Enterprise depends on the appropriateness of its leadership practices in accordance with Tseng (2018).

\section{Recommendations}

i. it has been proven by this study that there is a significant influence of strategic planning on sustaining Small and Medium Enterprise profit performance, therefore organizations are encouraged to be strategic in their planning as to continue the trend of profit making.

ii. Companies need to work more on their leadership practices and styles because the return on investment of Small and Medium Enterprise depends on the appropriateness of its leadership practices to a large extent.

iii. Managers are expected to be in the position of leading strategically in their business environment because there is a significant influence of strategic leadership on the social responsibility of Small and Medium Enterprise.

\section{Conclusion}

This study is an important study that helps to examine how the exercising of "strategic leadership" has influenced and sustained the performance of small and medium enterprises in Nigeria. This study also serves as a platform for managers to understand in-depth the necessity of adoption of appropriate leadership practices in their management because the findings reveal that the return on investment of Small and Medium Enterprise depends on the appropriateness of its leadership practices. The study will also assist new entrants into the industry to know the inherent value of strategic planning in order for them to be able to contribute to societal development through corporate social responsibility. Finally, the study will be a framework for conclusion for managers of businesses to appreciate the system of strategy implementation as it affects organizational value and performance in their industry of operations.

Funding: This research received no external funding

Author Contributions: All authors listed have made a substantial, direct and intellectual contribution to the work, and approved it for publication.

Conflict of Interest Statement: The authors declare that the research was conducted in the absence of any commercial or financial relationships that could be construed as a potential conflict of interest. 


\section{References}

Ahearne, M., Mathieu, J. \& Rapp, A. (2005). To empower or not to empower your sales force? An empirical examination of the influence of leadership empowerment behaviour on customer satisfaction and performance. Journal of Applied Psychology, 90, 945-955.

Alajmi, R. (2006). The effect of gender on job satisfaction and organisational commitment in Kuwait. International Journal of Management, 23(4), 834-844.

Almold, J. A., Arad, S., Rhodes, J. A. \& Drasgrow, F. (2000). The empowering leadership questionnaire. The construction and validation of new scale for measuring leaders behaviour. Journal of Organizational Behaviour, 21, 249 - 269.

Armstrong, M. (2009). Handbook of human resources practices (1 $1^{\text {th }}$ Edition). London, Philadelphia.

Ashibogwu, M. (2008). Common failure of family business. Business day, Monday, May 18.

Avolio, B. J. (2007). Promoting more integrative strategies for leadership theory building. American Psychologist, 62, 25-33.

Aime, F., Johnson, S., Ridge, J. W. \& Hill, A. D. (2010). The routine may be stable but the advantage is not. Competitive Implications of Key Employee Mobility Strategic Management Journal, 31, 75-87.

Avolio, B. J., Sosik, J. J., Jung, D.I. \& Benson, Y. (2003). Leadership models, method and application. Handbook of Psychology (277-308). Hoboken, N. J.: John Wiley \& Sons, Inc

Anthony, O. (June 2005). The effect of participative leadership style in organisation.

Atkin, D., Khandelwal, A. K. \& Osman, A. (2017). Exporting and firm performance: Evidence from a randomized experiment. Quarterly Journal of Economics, 132(2), 551-615.

Birou, L. M., Green, K. W. \& Inman, R. A. (2019). Sustainability knowledge and training: Outcomes and firm performance. Journal of Manufacturing Technology Management, 30(2), 294-311.

Bochnke, K. \& Bontis, N. (2003). Transformational leadership and organizational development. Journal, 24(1/2), 5-17.

Bloom, P. (2000). Circle of influence: Implementing shared decision making and participative management. Lake Forest, II. New Horizons.

Brown, D. R. (2011). An experimental approach to organizational development. $8^{\text {th }}$ Edition USA Pears on Education.

Bengelsdjik, S., Koen C. I. \& Noorderhaven, N. G. (2006). Organizational culture and relationship skills. Organizational studies, 27(6), 833-854.

Burke, C. S. (2006). What type of leadership behaviours are functional in terms? A meta-analysis leadership. The Leadership Quarterly, 17(3), 288-307.

Careless, S. A. (2004). Does psychological empowerment mediate the relationship between psychological climate and job satisfaction? Journal of Business and Psychology, 18(4), 405-425.

Chiek, F. (2001). Leadership behaviours: Effect on job satisfaction, productivity and organization commitment. Journal of Nursing Management, 9(4), 191 - 204.

Clement, B. \& Themba, M. (2013). Effect of participative leadership on organizational commitment. Comparing its effects on two gender groups among bank clears. African Journal of business management, 8(12), 451-459.

Davis, K. (2007). Human Behaviour at work. Quarterly, 17, 288-307.

Day, D. (2000). Leadership department. A review in context. Leadership Quarterly, 11, 581-613.

Day, D., Gronn, P. \& Sales, E. (2004). Leadership capacity in teams. Leadership capacity in teams. Leadership Quarterly, 15, 857-880.

Ehrhart, M. (2004). Leadership and procedural justice climate as antecedents of unit level organizational citizenship performance pers. Personnel Psychology, 57, 61-94.

Esposito, A. \& Sanchis-Llopis, J. A. (2018). Innovation and business performance for Spanish SMEs: New evidence from a multi-dimensional approach. International Small Business Journal-Researching Entrepreneurship, 36(8), 911-931.

Fry, L. W. (2003). Towards a theory of spiritual leadership. Leadership Quarterly, 10(2), 43-169.

Fenwick, F. J \& Gayle, C. A. (2008). Missing links in understanding the relationship between leadership and organisation performance. International Business and Economics Research Journal, 7(5), 1-12.

Goodavzi, M. (2006). Examining the relationship between manager's management style and performance MA thesis. Borojerd Branch, Islamic Azad University.

Goldstein, L. \& Ford, J. K. (2002). Training in organisation: Need assessment, development and evaluation. Thomson Learning, Belmont, CA.

Hoyt, C. L. \& Mulph, S. E. (2003). Group leadership efficacy and effectiveness. Group Dynamics, 7(4), $259-274$.

Hallen, B. (2017). Becoming Hewlett Packard: Why strategic leadership matters. Administrative Science Quarterly, 62(4), 45-46. 


\section{Strategic leadership and sustainability performance \\ of small and medium enterprises \\ Authors: Solomon Akpoviroro Kowo, Olufemi Amos Akinbola}

Hartline, M. D. \& Wooldridge, B. (2003). Guest perceptions of hotel quality, determining which employee groups count most. Cornell Hostel Restaurant Administration Quarterly, 44(1), 43-62.

Hou, X. and Li, W. (2019). The effects of industrial policy support on IPO performance: Evidence from listed enterprises of the Chinese SMEs board. Journal of Small Business Management, 57(2), 616-639.

Huang, X., Lunj, L. A. \& Gong, Y. (2010). Does participative leadership enhance work performance by inducing empowerment or trust? Journal of Organizational Behaviour, 31(1), 122-143.

Ijeoma, A. (2010). Unpublished Gender issues and leadership effectiveness in Nigeria labour union activities An Appraisal Nigeria. University of Lagos.

Joshi, A., Liao, H. \& Roh, H. (2011). Places demography researches a review and re-conceptualization. Journal of management, 37(2), 521-552.

Jung, D. \& Arlio, B. (2000). Opening the black box: An experimental investigation of the mediating effects of trust and value congruence on transformational and transactional leadership. Journal of Organizational Behaviour, 21, 949.

Javad, M., Nemotollah, S. \& Ali, K. (2013). Studying the effect of leadership participative Behaviours on Employee effectiveness, perception and performance (Kohdasht Municipality as cage study). International Journal of Academic Research in Business and Social Sciences, 3(1).

Liao, H. \& Joshi, A. (2004). Sticking out like a sore thumb Employee dissimilarity and deviance at work. Personnel Psychology, 57, 969-1000.

Levewis, M. W., Weish, M. A., Dehier, G. E. \& Green, S. G. (2002). Product development tension. The Academy Journal of Management.

Malagueno, R., Lopez-Valeiras, E. \& Gomez-Conde, J. (2018). Balanced scorecard in SMEs: Effect on innovation and financial performance. Small Business Economics, 51(1), 221-244.

Maliranta, M. \& Nurmi, S. (2019). Business owners, employees, and firm performance. Small Business Economics, 52(1), 111-129.

Moron, E. T. (2004). Participative leadership and style.

Ogundele, O. O. \& Okoruwa, O. V. (2006). Technical efficiency differentials in rice production technologies in Nigeria. African Economic Research Consortium, 154, 1-37.

Pitelis, Ch. N. \& Wagner, J. D. (2019). Strategic shared leadership and organizational dynamic capabilities. Leadership Quarterly, 30(2), 233-242.

Rowe, W. G. (2001). Creating wealth in organisations. The Role of strategic leadership. Academy of Management Executive, 15, 89-94.

Sine, W. D. (2016). The evolution of a new industry: A genealogical approach. Administrative Science Quarterly, 61(2), 20-21.

Ssebunya, B. R., Schader, Ch., Baumgart, L. et al. (2019). Sustainability performance of certified and non-certified smallholder coffee farms in Uganda. Ecological Economics, 156, 35-47.

Tseng, M.-L., Lim, M. K. \& Wu, K.-J. (2018). Corporate sustainability performance improvement using an interrelationship hierarchical model approach. Business Strategy and the Environment, 27(8), 1334-1346.

Yuki, G. (2002). Leadership in organization. $5^{\text {th }}$ Edition Eagle wood Cliffs, N J prentice - Hall. 